\title{
Other Construction and Related Workers
}

National Cancer Institute

\section{Source}

National Cancer Institute. Other Construction and Related Workers. NCI Thesaurus. Code C122540.

Construction and related workers not specifically identified elsewhere. 